\title{
Participatory Budgeting in Europe: Potentials and Challenges
}

\author{
YVES SINTOMER, CARSTEN HERZBERG and ANJA RÖCKE
}

\begin{abstract}
The 'transfer' of participatory budgeting from Brazil to Europe has been a highly differentiated process. In Porto Alegre, this innovative methodology enabled democratization and social justice to be articulated. In Europe, participatory budgeting relies on multiple procedures, and it is therefore necessary to give a clear methodological definition of it so that cases can be coherently compared and ideal-types constructed to understand the variety of concrete experiments. The six ideal-types we propose (Porto Alegre adapted for Europe; representation of organized interests; community funds at the local and city level; the public/private negotiating table; consultation on public finances; proximity participation) show striking differences that are highly influenced by existing participatory traditions. It is, above all, with the models Porto Alegre adapted for Europe and community funds that an 'empowered participatory governance' can develop and that a fourth power, beyond the three classical ones, is developing - that of the citizenry when it directly (or through delegates) assumes a decision-making power. However, other models have their strengths, too, for example with regard to the reform of public administration which is a critical aspect in the search for 'another possible world'.
\end{abstract}

Participatory budgeting has been one of the most successful participatory instruments of the past 15 years. Since it was invented in Porto Alegre (Brazil), it spread first in Latin America, where probably more than 1,000 among the 16,000 municipalities had introduced it by 2006 (Cabannes, 2006), and then over the entire globe. Participatory budgets emerged simultaneously in seven, mainly Western, European countries. Procedures are currently underway or are at a preliminary stage in four further countries. Altogether, in 2008, there are more than 100 European cities with a participatory budget. Among them are large cities, such as Seville in Spain, which has more than 700,000 residents and districts of the capital cities of Paris, Rome, Lisbon and Berlin (a first attempt was also made in 2005 in London). ${ }^{1}$ However, medium-sized cities, such as Hilden and Emsdetten in Germany, and small communes, such as Grottamare or Altidona in Italy, ${ }^{2}$ have also adopted the procedure (see Figure 1).

1 London-Harrow: 211,000 residents; Paris-XX: 180,000 residents; Rome-XI: 140,000 residents; Berlin-Lichtenberg: 252,000 residents.

2 Hilden: 56,000 residents; Emsdetten: 35,000 residents; Grottammare: 14,700 residents; Altidona 2,600 residents. 


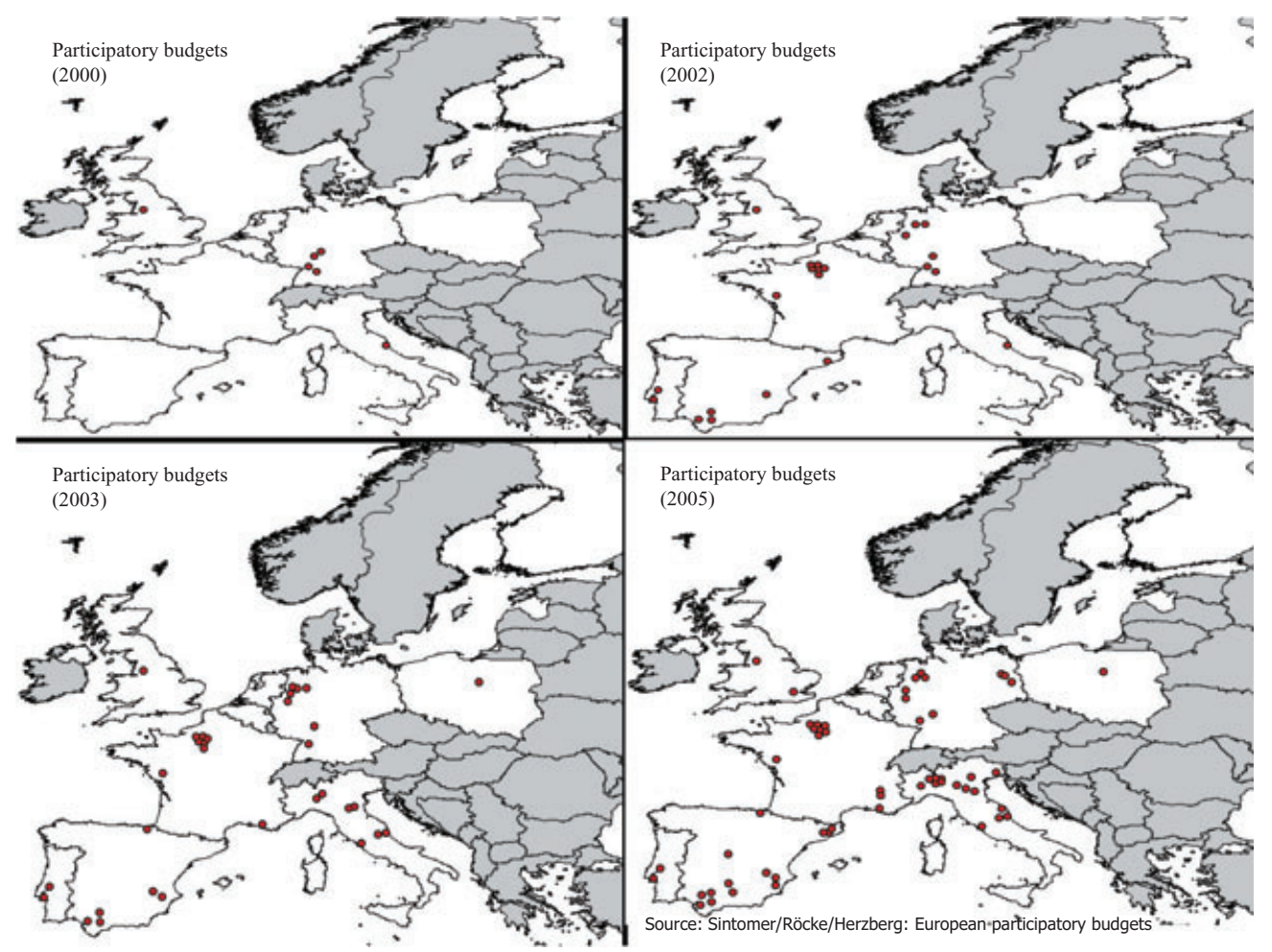

Figure 1 Participatory budgets in Europe 2005 (source: Sintomer et al., 2005)

Research into participatory budgeting forms part of a larger field of interest in democratic innovations, both theoretical and practical. That field contains a wide range of participatory devices (consensus conferences, deliberative polls, citizen juries, etc.), and a number of new concepts (empowered participatory governance, countervailing power, participatory publics, fourth power, etc.). While participatory democracy and deliberative democracy have been the two main basic theoretical frames that have enabled the research, they have been interpreted in quite different ways. Some, following Habermas (1996), have insisted, for example, on the conditions for a good participatory deliberation; others, in a post-Marxist tradition, have focused on the importance of participatory devices in and for social struggles. A comprehensive presentation is not within the scope of this article, which will follow a more empirical path. Field research on participatory experiments has, until now, followed three steps. In the first, monographic analyses have been conducted of various cities and different procedures, sometimes comparing two or three cases. In the second step, conferences and collective books have allowed more experiments to be compared, but on the basis of field research conducted with different methodologies and theoretical categories (Fung and Wright, 2003; Bacqué et al., 2005; Santos, 2005). Our present article will present some of the results of a study that is part of a third step: we have conducted integrated research in more than 20 cities, relying on the same methodology and the same concepts (Sintomer et al., 2005). ${ }^{3}$

3 Research for 'Participatory budgeting in Europe' has been conducted by the Centre Marc Bloch in Berlin, in cooperation with the Humboldt University in Berlin and using funds from the Hans-Böckler-Foundation and from the CNRS (France) (see www.buergerhaushalt-europa.de). We have worked in ten different countries and extensive analyses were conducted between 2002 and 
Participatory budgeting was invented in a quite specific context. Once it has been imported into and adapted for such different places as Seville (Spain), Berlin (Germany), or Płock (Poland), can one still speak of one single (although complex) dynamic, or does one have to state that the name tends to be the only common link, labelling quite different realities? Is the expansion of participatory budgeting only a fashion, or a sustainable path towards a new type of urban policy? What kinds of participatory budgets exist in Europe and to what extent and under which conditions can they contribute to the modernization of the administration, the renewal of democracy and the strengthening of social justice? In the following, we will briefly describe the origins of participatory budgeting in Porto Alegre, Brazil, and follow its path to Europe. We want to demonstrate that participatory budgeting is not limited to one model. Rather, it may assume different forms. We will subsequently present a typology of the various procedures that are used and discuss their potential effects and limits. A broader analysis should engage with the social dynamics, the normative frames and the relationship between representative and participatory politics that are at stake and build another, more global, typology (Sintomer et al., forthcoming), but that is beyond the scope of this article. In conclusion, we will present a few remarks on the potential and limits of participatory budgeting in Europe.

\section{The idea of Porto Alegre}

Participatory budgeting emerged in Brazil at the end of the 1980s in a context which differs significantly from the situation in Western Europe - most notably because Brazil is one of the countries in the world with the greatest income gap, and because in its 'delegative democracy' (O’Donnell, 1994) the constitutionally guaranteed democratic institutions do not operate as intended, since politics and the administration are characterized by corruption and clientilism. Especially at the local level, it is common for leading politicians to be dependent on the economy and to purchase votes with money and hollow promises. The city of Porto Alegre partly differs from this tradition. The standard of living there is above the average of other Brazilian cities, and the participatory budget has contributed to this circumstance. Moreover, it has provided for a reversal of priorities: primary health care was set up in the living areas of the poor, the number of schools and nursery schools was extended, and in the meantime the streets were asphalted and most of the households have access to water supply and waste water systems. What were the conditions that brought about this development, and how has participatory budgeting rendered possible a more efficient government, a reallocation of resources in favour of the most disadvantaged people and a democratization of politics?

Rebecca Abers (2000), one of the first observers of the participatory budget in Porto Alegre, explains that it emerged due to a 'window of opportunity', which opened in the aftermath of the electoral victory of the Labour Party (Partido dos Trabalhadores [PT]), ${ }^{4}$

2005 in 20 cities. Basic data have been collected in more than 30 additional cities. The following individuals participated in the project as associated researchers: Belgium: Ludivine Damay, Christine Schaut; France: Marion Ben-Hammo, Sandrina Geoffroy, Julien Talpin; Great Britain: Jeremy Hall; Italy: Giovanni Allegretti (coordinator), Pier Paolo Fanesi, Lucilla Pezzetta, Michelangelo Secchi; Netherlands: Hugo Swinnen; Poland: Dorota Dakowska, Elzbieta Plaszczyk; Portugal: Luis Guerreiro; Spain: Ernesto Ganuza.

4 The PT is a pluralist left-wing party which emerged from the 1970s trade union movement, which, in particular in the industrial area surrounding São Paulo, fought with strikes against the then dictatorship. Middle-class intellectuals, supporters of liberation theology, members of former left-wing parties and extreme left groups as well as social movements in the cities and in the country joined it. The Landless Peasants Movement was for a long time considered to be the group that was most apt to activism amongst those supporting the party. While the main faction of the party can be described as leaning toward social democracy, the PT in the state of Rio Grande do Sul, of which Porto Alegre is the capital, stands more to the left. 
in 1988. At the time the PT was at the beginning of its rise, and it had to prove that its style of government stood out from that of the other parties. It was looking for a way of translating the grassroots self-conception of the party into municipal politics. However, it was not only the new government which pushed the participatory budget. Civil society, in particular district initiatives, also demanded more co-decision-making capacity. The invention of this new device was, therefore, the result of a conjunction of top-down and bottom-up processes. The spoils system that exists in Brazil proved to be helpful in the creation of this new space for citizen participation. It is important to underline that participatory budgeting in Porto Alegre only slowly evolved into a new form of participatory government. However, when the PT lost the office of mayor to the opposition in 2004 after 15 years in power, the participatory budget had been integrated to such an extent that the new government did not dare to abolish the procedure, even though it has reduced its scope.

International scholars (Abers, 2000; Herzberg, 2001; Avritzer, 2002; Allegretti, 2003; Baiocchi, 2005; Gret and Sintomer, 2005) have shown that three basic principles have been particularly important in the setting-up and functioning of this procedure.

1 The first principle is grassroots democracy, carried into effect via citizens' assemblies in the 16 districts of the city. The aim of these assemblies is to determine priorities and to elect delegates and representatives who follow up on the development of suggestions put forward. In addition to investments, political guidelines for the design of municipal policies on such issues as education, health, culture, etc are discussed. Priorities are selected on the basis of the principle of 'one man one vote', so that every citizen has the same number of votes at his or her disposal.

2 Social justice, the second principle, is realized via an allocation formula. The funds which are at the disposal of each of the investment areas are distributed among the districts, taking into consideration the number of residents and the quality of the infrastructure available, as well as the local list of priorities. These three criteria ensure, for example, that districts with a deficient infrastructure receive more funds than areas with a high quality of life.

3 Citizen control, the third principle, is realized by means of boards, such as the Council of the Participatory Budget, which convenes once a week for two hours. Its members are elected during the basic assemblies of the districts. It is their duty to ensure that the priorities of the districts are taken up in the budget to the largest extent possible. Independent NGOs train the representatives of the participatory budget in order to enable them to co-plan with the administration. In addition, the Council of the Participatory Budget is involved in the allocation of public contracts.

Overall, even though some serious challenges had to be faced and were not completely overcome (Gret and Sintomer, 2005), these three principles led to a real empowerment of civil society and, most notably, of the working class. It is very important to note that this achievement was due to a combination of a strong and pragmatic political will on the part of the local government on the one hand, and of bottom-up mobilization on the other side (Santos, 2005). In Brazilian cities where participatory budgeting was simply a top-down process, Leonardo Avritzer has demonstrated that the results have been very different (Avritzer, 2005; 2006). The Porto Alegre experiment has implied an innovative participatory institution and a 'countervailing power', and this combination confirms what scholars have analysed in other contexts as the preconditions for an 'empowered participatory governance' (Fung and Wright, 2003). During a decade, civil society has been strengthened. More and more citizens have joined initiatives and associations in order to present their suggestions successfully in the process of participatory budgeting. Clientilistic structures were largely overcome in these new organizations, because democratic and transparent rules replaced negotiations behind closed doors. In addition, participatory budgeting has led to a reorientation of public investments towards the most disadvantaged districts. This has 
come about because the process has been invested in mostly by the working class, because it has permitted the formation of a 'plebeian public sphere' (Baierle, 2006: 127), and because it has contributed to an improvement of public services and infrastructures. Brazilian scholars have recently demonstrated with a convincing methodology that this redistributive effect has characterized other important participatory budgets than Porto Alegre's (Marquetti et al., 2007).

Interestingly enough, in this very peculiar context, a procedural model has been invented that, year after year, has been considered as a source of inspiration by other cities. Four times, in 2001, 2002, 2003 and 2005, the World Social Forum met in the Rio Grande do Sul capital, and this has been a strong factor in the diffusion of participatory budgeting. Since those years, Porto Alegre has become a symbol of a new type of more participatory democracy. Very surprisingly, along with the anti-globalization movement, international organizations which are far from 'subversive', such as the World Bank and UN-Habitat (UNDP, 2001), have analysed Porto Alegre as an example of best practice with regard to urban policies. The hundreds of other participatory budgets in Latin America have had very different political, social and administrative outcomes, however (Cabannes, 2003).

\section{What is a participatory budget?}

Any comparative research has to face a definition problem, which is even more difficult with participatory budgeting in Europe where, in contrast to Latin America, very different forms of citizen participation in the budget allocation procedure exist. In some cases, the term 'participatory budget' refers merely to an informative event connected with the budget without including consultation with the citizens. Other examples, however, which are locally not referred to as 'participatory budgets', may feature an intensive participation procedure. This is why one cannot rely on a 'nominalist' definition, based only on the denomination of the process as 'participatory budgeting', in order to make a comparison possible. An ontological definition that would aim to define what participatory budgeting should be, at any time and in any country, does not seem legitimate, both because this procedure is different in Latin America and Europe and because sociologists can hardly define the essence of a procedure or institution. A political (or normative) definition would be possible, but is not the aim of this article. It is therefore necessary to develop a methodological definition, which includes a set of minimal requisites in order to clearly differentiate this participatory procedure from others (such as neighbourhood funds) and which, at the same time, is comprehensive enough to give sufficient leeway to procedures with different specificities.

Broadly speaking, participatory budgeting allows the participation of non-elected citizens in the conception and/or allocation of public finances. In order to give a more precise definition of the process, five criteria need to be added (Sintomer et al., forthcoming): (1) the financial and/or budgetary dimension must be discussed; participatory budgeting involves dealing with the problem of limited resources; (2) the city level has to be involved, or a (decentralized) district with an elected body and some power over administration (the neighbourhood level is not enough); (3) it has to be a repeated process (one meeting or one referendum on financial issues does not constitute an example of participatory budgeting); (4) the process must include some form of public deliberation within the framework of specific meetings/forums (the opening of administrative meetings or classical representative instances to 'normal' citizens is not participatory budgeting); (5) some accountability on the output is required.

Defined by these five criteria, participatory budgeting is a new and highly dynamic process in Europe. Within five years, the number of participatory budgets increased from 6 in 2000 to 55 in 2005 and there are more than 100 experiments in 2008 (see Figure 2). The number of city residents able to take part in a participatory budget has increased even 


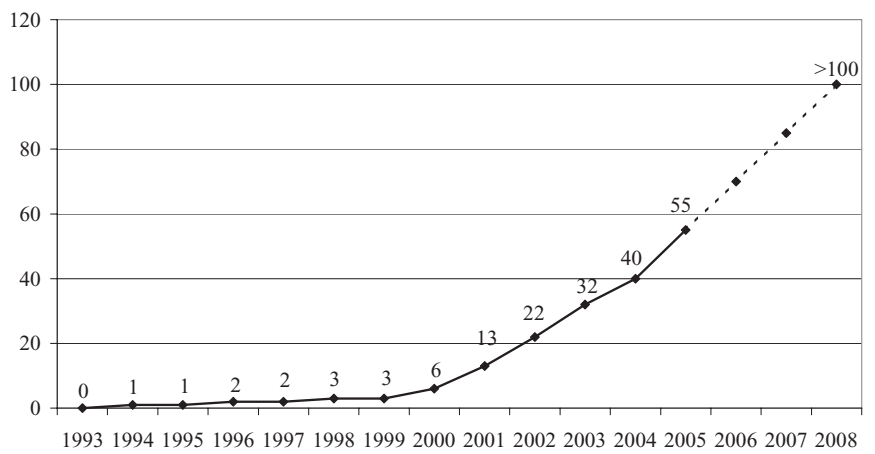

Figure 2 Number of participatory budgets in Europe

more rapidly. Within two years it doubled to nearly five million in 2005. In that same year, $5.2 \%$ of the population in Spain already lived in cities with a participatory budget - however, the rate was only $1.4 \%$ in Germany and slightly above or below $1 \%$ in Portugal, Italy, France and Great Britain. (That is nothing compared with Brazil, where the rate was 43\% in 2001-2004 (Marquetti, 2005).) Along with Spain, a particularly strong growth of cases is observable in Italy and, more recently in Portugal, while Great Britain seems in the process of becoming one of the leading countries in this field in the next few years.

\section{A procedural typology}

With such a high number of experiments, any comparative research faces two opposite risks. The first one is to explain the variety of the cases with a single, one-sided evaluation (stating for example that participatory budgeting in Europe is only a policy problem with no political impact) or to use a mere dichotomy ('real' participatory budgets are an alternative to neoliberal globalization, others are pseudo-participatory budgets). The second one is to get lost in the diversity of the cases and to be unable to present a global panorama. In order to overcome these problems, we have created in the Weberian manner a typology of participatory budgeting procedures, which has to rely on ideal-typical models that are constructed in the process of the empirical study. It can give the various poles of a semi-conceptual map (see Figure 3 ) in which it is possible to place the concrete experiments (which never correspond exactly to one ideal-type). Based on a set of criteria, ${ }^{5}$ six models can be differentiated, which are strongly influenced by a path-dependency:

- Porto Alegre adapted for Europe

- Participation of organized interests

- Community funds at local and city level

- The public/private negotiating table

- Proximity participation

- Consultation on public finances

5 The criteria are: (1) Origin of the process; (2) Organization of the meetings (neighbourhood, city and/or thematic assemblies; closed vs. public meetings, etc.); (3) Type of deliberation (topics of discussion; modalities of discussion, etc.); (4) Position of civil society in the procedure (type of participating citizens, co-elaboration of methodology, etc.). In addition, the strengths, weaknesses and challenges of each model have been analysed. 


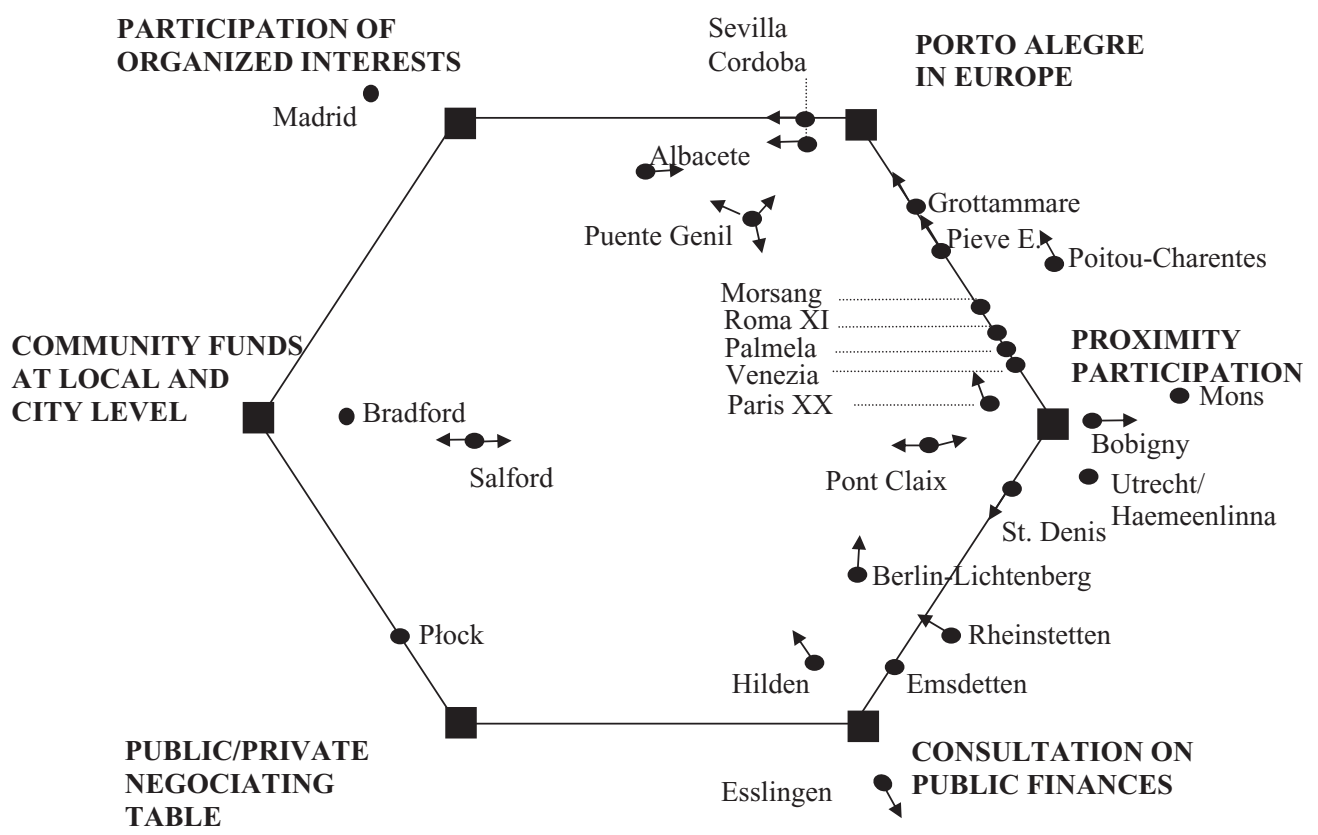

Figure 3 Typology of procedures

For the sake of a short presentation, we will analyse the ideal models in pairs and discuss some practical experiments.

\section{'Porto Alegre adapted for Europe' and 'Participation of organized interests'}

In some European experiments where the influence of the anti-globalization movement has been particularly important, the model of Porto Alegre has directly influenced the set-up of a completely new procedure. In the Spanish town of Cordoba $(320,000$ residents), for example, the participatory budget (introduced in 2001) can largely be understood as the ideal-type 'Porto Alegre adapted for Europe'. However, in other cities, the impact of the Brazilian example has been more indirect, such as in the cases in which participation is not directed towards individual citizens. In the second ideal-type, secondary associations, NGOs, unions and other organized groups are the main actors. This model is based on a neo-corporatist logic, and we call it 'Participation of organized interests'. Very often, it develops in places where the previous participatory tradition has been based on the contribution of associations and interest groups to the definition of public policies in particular sectors. Although there is so far no direct example of the model of organized interests in Europe, some experiments are moving in this direction. The participatory budget in Albacete (150,000 residents) can be considered as a hybrid of both the 'Porto Alegre' and the 'organized interest' models.

The content of discussions constitutes a second difference between the two types. In the model 'Porto Alegre adapted for Europe' discussions primarily deal with concrete investments and projects, whereas the discussion of broad political guidelines is at the centre of the 'Participation of organized interests' process (i.e. general orientation of housing, education, environmental or local traffic policies). A further difference is the way citizens' suggestions are dealt with. In the model 'Porto Alegre adapted for Europe' there is a high pressure to realize the proposals which emerge during the participatory budget process because the local government is bound by its own commitment to accept them. Although the municipal council technically continues to 
be responsible for the final decision on the budget, citizens can be considered to have a de facto (co-)decision-making capacity. As in the Brazilian case, this model contains an allocation formula for investments. However, the criteria are not necessarily the same as in the Brazilian context. Other indicators can be used, such as the number of welfare recipients in the district, participation in meetings or the degree to which citizens themselves realize the proposed projects. In the model 'Participation of organized interests', rules may be more informal than in the Porto Alegre model and may lead to a mere consultative process.

One strength of both models rests in the potential for good-quality deliberation. ${ }^{6}$ Participants not only discuss matters in a large plenum, but may also do so in smaller fora, committees or on delegate boards. In these settings, an in-depth discussion, allowing the development of detailed suggestions to solve problems and the clarification of important matters, becomes possible. This may even include the fact that participants develop expert's reports on the equipment of schools or on the improved integration of minorities. One challenge for both models consists, however, in connecting the procedures with a comprehensive modernization of the entire administration. A further challenge concerns the resolution of potential conflicts between individual citizens' participation and that of organized interests. In some experiments close to the Porto Alegre model, this has proved to be problematic, for instance when established associations and initiatives have feared disadvantages with regard to their promotion.

\section{'Community funds at local and city level' and 'The public/private negotiating table'}

The 'community funds' and 'public/private negotiating table' models have only played a marginal role in European participatory budgeting so far. Nevertheless, they represent a potentially strong basis for the future development of participatory budgeting, most of all in Great Britain and in Eastern Europe. In both types, there is a fund for investments or for projects in the social, environmental and cultural areas, respectively. Such a fund has existed, for example, in the British city of Bradford (467,000 residents) and in the Polish town of Płock (128,000 residents). Another specificity of these models is that they are relatively independent of the municipal budget, because the money at stake does not come, or comes only in part, from the local administration. Therefore, the municipal council does not have the last word with regard to the acceptance of proposals. Rather, it is a committee, a commission or an assembly of delegates which generates the priorities. Organized groups, such as local or community associations and NGOs, are at the core of both procedures, but business is excluded from one of them and is central in the other. The deliberative quality can be considered to be fair, since several meetings take place with a manageable group of participants.

In the case of 'The public/private negotiating table', private enterprises and possibly international organizations raise part of the money. The oil company ORLEN S.A. for example contributes 50\% to a fund in Płock of altogether approximately 300,000 Euros, in addition to the municipality and the UN development programme. This financial involvement enables the private sponsor to influence the design of the procedure, whereas citizens, who give no money but apply for it, only play a secondary role. This model may be developed when international actors try to include citizen groups or NGOs in public/private partnerships. The UNO program Habitat has officially adopted participatory budgeting (Cabannes, 2004), but it soon largely diverged from the Porto Alegre model in defining this instrument as an innovative mechanism which tends to promote the involvement of local governments, the private sector and civil society in the

6 Criteria for a 'good' deliberative quality include, amongst others, the inclusiveness of the process, the mutual exchange of arguments and the existence of clear rules. Various definitions of deliberation can be found in the literature about deliberative democracy that has exploded in the last couple of years (Cohen, 1989; Bohman and Rehg, 1997; Elster, 1998). 
reparation of communal finances'. ${ }^{7}$ The influence of the capital of Rio Grande do Sul is therefore indirect. ${ }^{8}$

By contrast, the combination of a strong local participatory tradition with the ideas of Porto Alegre has led to the extension of a local, community fund model to the city level. In this model, participants decide upon the rules of the community fund autonomously, whilst business is excluded. Funding is provided through specific policy programmes, for example for urban renewal. In this model, the promotion of socially disadvantaged groups is a key feature. In 2004, for instance, a participatory budgeting fund in the British city of Bradford of more than 875,000 Euros was reserved exclusively for groups from disadvantaged areas. Moreover, the participants in the 'community funds' ideal-type realize the projects themselves. While this is possible with the public/private negotiating table, too, it is not a necessary requirement.

These two models have advantages and drawbacks. The link to the local political structure, for instance, is weak or non-existent, even though the municipal council retains a certain influence since it raises part of the money. In 'The public/private negotiating table', the influence of private investors depends on the size of their contribution, but a radical shift towards more social justice is improbable. Likewise, the 'Community funds' model presents new possibilities for participatory budgeting. National and Europe-wide programmes for the promotion of cities and infrastructure could, for example,. be linked locally with the participatory budget and promote disadvantaged neighbourhoods or groups of residents. Both models share the advantage that they provide for distinctive citizen involvement, because those who participate also implement the projects.

\section{'Proximity participation' and 'Consultation on public finances'}

While examples of the 'Proximity participation' model can be found predominantly in France, the 'Consultation on public finances' model is characteristic of participatory budgets in Germany. Both have in common that they include merely consultative processes. This means that the results of the discussion are summarized by the local administration, and not by the participating citizens. Unlike the models presented so far, participants here do not vote or develop priorities for projects. Rather, it is a process of 'selective listening', i.e. the local government can freely (and arbitrarily) integrate some of the proposals into its public policies after the participatory process. Furthermore, civil society only has a weak influence with regard to the design of the procedure. It needs to be pointed out that these models do not pursue any social goals, and that no distributive criteria exist in the process. A further common feature is that associations barely play a role within the procedure. Participation is carried out via open councils to which individual citizens have been summoned via announcements in the media, by letter or via personal contact. In Germany and in some French experiments, participants are (supplementarily) mobilized on the basis of random selection from the register of electors (Röcke, 2005). These individuals receive a personal invitation by the mayor to attend the citizens' forum. This method is, amongst others, applied in Emsdetten (35,000 residents), Hilden (56,000 residents), Vlotho (21,000 residents) and in the Berlin district of Treptow-Köpenick (233,000 residents).

The two procedures differ in their origins. The 'proximity' model usually relies on previous participatory devices such as neighbourhood funds or councils, which tend with participatory budgeting to be linked together in a single device. This development takes place following the ideological influence of Porto Alegre, but the actual

7 Official circular from UN-HABITAT, 28 July 2005.

8 In turn, after the electoral defeat of the PT in 2004, this model influenced the participatory policy of Porto Alegre's new local government: 'local solidarity governance', in which participatory budgeting is conceived to be only one dimension among others, is supposed to integrate local business in the process - with scarce results until now. 
similarities remain very limited. The 'Consultation on public finances' model may retain some influence from Porto Alegre, but is de facto more derived from participative trends in New Public Management strategies. In Germany, it was imported from the New Zealand city of Christchurch, and the Brazilian experiments had an impact only later on, leading to the emergence of mixed models. The 'proximity' model mostly involves neighbourhoods and relates to investments at this level. At the level of the city as a whole this model no longer deals with investments, but with general policy goals ('a beautiful city'). Generally speaking, the term 'proximity' has two meanings. On the one hand it refers to a geographical proximity, in the sense, for example, of organizing several meetings within neighbourhoods and not just one meeting in the town hall; on the other hand, the term stands for a close contact between municipal leadership or the administration and the citizens. According to this model, the mayor of Bobigny (45,000 residents) organizes open meetings twice a year in order to respond to citizens' concerns. The model 'Consultation on public finances' first and foremost deals with rendering transparent the financial situation of the city. Information on the overall budget is disseminated via brochures, the internet and press releases. There are two versions of the model. In the more widespread variant, public services and areas of municipal responsibility are presented, for example the revenues and expenditures of libraries, swimming pools and nursery schools and street-cleaning, waste water treatment or waste disposal, respectively, etc. Citizens may voice their suggestions in an open plenum or in specific fora. The second variant aims at balancing the budget deficit. In the North Rhine-Westphalian town of Emsdetten, for example, the participatory budgeting process for the year 2002 was based upon five options for a balanced budget: cuts in personnel costs and operating expenses, the reduction of voluntary duties and responsibilities, a withdrawal from the reserve or an increase in taxes and fees. Using a questionnaire, every participant was asked to develop a suggestion of his or her own, based on the combination of the possibilities mentioned. At the end of the event an overall recommendation of the citizens' forum was calculated on the basis of the individual opinions. In general, the deliberative quality of the model is low, because in most cases there is barely any time for a more intensive discussion. With the 'Proximity participation' model, by contrast, the quality of the debate may be better, because citizens sometimes work in small groups that meet repeatedly over a longer period of time.

The model 'Consultation on public finances' is interesting in the sense that it is part of an overall modernization of local bureaucracy, even though a discussion limited to one or two meetings a year can hardly produce huge effects. Furthermore, citizen participation only constitutes an 'appendage' of this modernization process, with no direct relation to social problems and to a renewal of politics. The model 'Proximity participation' may induce a discussion between citizens and the administration/council members, but hardly produces modernization effects at the city level. In both models, accountability is low with regard to the realization of proposals and the autonomy of civil society is weak.

\section{Impacts of participatory budgeting in Europe}

It is difficult today to analyse systematically the effects of participatory budgeting in the European experiments. First, we are dealing with very recent procedures. Second, it is very difficult to isolate this particular factor from other, more general influences (e.g. on electoral turnout). Quantitative data which would allow this kind of analysis is not available today, and the main results of our study have been produced by qualitative methods and through an ethnographic study of the different processes and contexts. Furthermore, the effects of participatory budgeting strongly differ from model to model, and also depend on the specific socio-economic and political context. Despite these 
problems, what can be said today about the contribution of participatory budgets to administrative modernization, the renewal of politics and a strengthening of social justice?

A clear link can be found between participatory budgeting and the demand for more transparency. This applies to the overall budget situation as well as to the projects discussed within participatory budgeting. So far, however, transparency has not been sufficient to actually enable citizens to control the finances of the city. Beyond transparency, four other trends of administrative modernization have been analysed in a variety of cases: an improvement of public services based on the citizens' proposals, better cooperation between individual administrative departments, a speed-up of internal administrative operations and greater responsiveness on the part of public administration. By contrast, cost reduction and structural reforms of the administration through participatory budgeting tend to be the exception. It is only in some cities, for instance in Spain, that participatory budgeting has constrained the administration to describe its performance by giving straightforward results, to improve the coordination of departments and also to present administrative activities in a transparent manner, both internally and externally. Nonetheless, it seems highly plausible that one important criterion of the success of participatory budgeting is the link between participation and a comprehensive modernization process. However, although this pragmatic goal is more developed in the 'Consultation on a public finance' model, the achievements have been rather disappointing. The explanation is that another important criterion of success, good deliberation, is hardly to be found in this type of participatory budgeting and its incidence is a great deal higher in the Porto Alegre model. Modernization effects mainly occur in those places where ample discussion takes place within general assemblies and participatory councils.

The potential political consequences of participatory budgeting are even more contrasted. In many cases, participatory budgeting has contributed to improved communications between citizens, the administration and the local political elite. If participatory budgeting will ever play the intermediate role that political parties had in the past, is an open question, however. The widespread expectation that the turnout of voters would increase with participatory budgeting is not supported by the empirical research. In a number of cases, even if better results for the governing party can be observed, this is probably not a direct result of the participatory budgeting process. A more adequate explanation would seem to be that the increased turnout is the result of a participatory approach that local government has adopted generally. Participatory budgeting can have positive impacts on the political culture and competences of participants. In some cases, it leads to a better coordination of civil society, especially in cases where regular meetings are held over a longer period of time instead of there being one single annual event. However, municipal councils rarely use the citizens' concrete proposals as a 'compass' for their final decisions (with a few exceptions in Spain and Italy). This is, among other things, due to the fact that central aspects of the budget are often not discussed in the participatory process. In any case, real political impacts from participatory budgeting in Europe will only make themselves felt in a long-term perspective. Up to now, the political dimension is far less present in Europe than in Porto Alegre.

The contrast between the situation in Europe and Brazil is even sharper with regard to the aspect of social justice. The Italian city of Grotammare is the only example of fundamental social improvements that have taken place through participatory budgeting. In some cities, however, marginal groups could be mobilized for the process, for example, in the Spanish city of Albacete. Here, the ethnic groups of Sinti and Roma as well as migrants hold permanent seats on the delegate board of the participatory budget and were able to achieve the construction of a community centre that meets their needs. In order to achieve more global effects in terms of social justice, participatory budgeting must include the participation of different groups and of different social strata (e.g. through appropriate procedures and distributive criteria). This has been the case, although on a modest scale, in some experiments oriented towards the model of 'Porto Alegre adapted for Europe' and of 'Community funds'. 


\section{Conclusion}

In this article, we have shown that the importation of Porto Alegre into Europe has been a highly differentiated process. On this continent, participatory budgeting does not rely on one procedure but rather on a multitude of devices. In a work of comparative research, it is therefore necessary to give a clear methodological definition of participatory budgeting and to construct ideal-types in order to present a global panorama of the variety of concrete experiments. The six models we proposed (Porto Alegre adapted for Europe; Participation of organized interests; Community funds at the local and city level; The public/private negotiating table; Consultation on public finances; and Proximity participation) show striking differences which are highly influenced by existing political traditions of participation and of democracy.

Up to now, participatory budgeting has been mostly taken up by left-wing politicians, not only in the South (Chavez and Goldfrank, 2004), but also in many European countries (especially in France, Italy, Spain and Portugal). However, with regard to the situation in Europe, participatory budgeting has not (yet?) produced those results that politicians and activists hoped to achieve. Is this just a matter of time and of different political circumstances? A 'window of opportunity' as in Porto Alegre can not be created ex nihilo, and the 'institutional kit' of participatory budgeting alone hardly produces the same outcomes in Europe as in Brazil. There exist, however, 'succesful' examples of participatory budgeting (especially in Spain and Italy), where a serious process with clear rules, an active civil society and a local administration and executive that learnt to cooperate led to considerable results. In other cases, the process was labelled as participatory budgeting but had more in common with a 'show' (for a single politician or the city as a whole) than with a device of citizen engagement. In this situation it is crucial to keep a critical distance and not to confuse ideological discourses and real achievements. These depend partly on the concrete dynamic of collective action and partly on the intrinsic interest of the various procedures.

It is above all in the models 'Porto Alegre in Europe' and 'Community funds at neighbourhood and city levels' that an 'empowered participatory governance' (Fung and Wright, 2003) can develop. In these models, a fourth power, beyond the three classical ones, is developing - that of the citizenry, when it directly (or through highly controlled delegates) assumes a decision-making power (Gret and Sintomer, 2005), enabling the emergence of a 'strong public' (Fraser, 1996: 89) in the participatory device. It is, however, only when this institutional innovation is accompanied by social mobilization that one can really speak of an 'empowered participatory governance', and the cases where the working class is central to the process and where a 'plebeian public sphere' can develop are only a minority. In all the other procedural models, there may be participatory governance but it can hardly be empowered: the Proximity participation and Consultation on public finances models are only consultative, which prevents the creation of a fourth power. The Participation of organized interests and The public/ private negotiating table models may give a decisional power to the participatory device, but they can hardly make fundamental political and social changes possible. In these four models, the imperative of consensus is very high and one cannot speak of a cooperative resolution of real conflicts. It is therefore very probable that social movements will potentially mobilize out of participatory budgeting rather than through it.

However, this is not the whole story and one cannot simply say that there is one good model or even two good models. For example, in the 'Community funds' and 'The public/private negotiating table' models, the direct involvement of citizens in the implementation of projects challenges Habermas and Avritzer's view that participation can legitimately only concern the decision making-process and the control of administration and has to leave the monopoly of implementing public policies to public servants. It permits the development of a community and voluntary sector, which is perhaps not the ideal solution to any problem but cannot be considered as a priori inferior to public administration or the market in terms of efficiency or orientation towards the 
common good. This was not addressed so centrally in the Porto Alegre experiment. And even if 'The public/private negotiating table' seems to be inhospitable to any serious attempt to invert social priorities, it underlines that what happens in the private sector remained almost completely out of reach in the Porto Alegre model, even if this sphere is crucial for urban development.

Another question concerns the modernization of public administration. In order to challenge the neoliberal trends oriented towards market criteria, the public sector has to prove that it can be efficient and provide good services to the public, but it cannot do so without changing its internal structures and management procedures and without giving the public a voice in this process. Some of the scholars of Brazilian experiments have underlined this dimension, most notably Luciano Fedozzi (1999; 2000), but the international literature has not been until now conscious enough of this crucial challenge. The Consultation on the public finances model, even if it has led to disappointing results, has more centrally addressed this point than the Porto Alegre in Europe model. This is important because the potential contribution to modernization is much more developed than the political and social dimensions in European participatory budgets, and this appears to be one their most interesting features compared with Latin American experiments.

Generally speaking, a process which can be combined with certain existing traditions of participation might lead to more results than an 'articifial' process without any links towards existing structures - and, at the same time, radical innovations seem necessary to challenge the present asymmetric power relations. This is partly a dilemma, and this is also the reason why there exist multiple ways towards more just and more democratic urban development in Europe, depending on the respective situations, and not one 'royal road'. As other scholars have rightly stated, it is time to reject the 'black and white' analysis that prevailed in the past (Chavez and Goldfrank, 2004: 6). Participatory budgeting can be a powerful process for achieving more democracy, social justice and transparent administration, but it is surely not the only one. Its 'success' partly depends on the political and financial autonomy of local governments but it cannot, in the long run, be imposed only in a top-down manner, without any 'countervailing power', if it is to contribute to make 'another world possible'. The current developments in the UK provide an interesting case in this regard. The Secretary for Communities and Local Government, Hazel Blears, has recently declared that every local authority should have set up a participatory budgeting procedure within five years - with the 'Community funds' model in mind. What will happen if this becomes true? Will participatory budgeting only become another 'tool' of participation in the New Labour agenda, or will it lead to fundamental changes in the relationship between local citizens and the city government, as well as between local authorities and the central state and in the actual balance of power in urban policies? The future is open but will not depend only on the political will of the national and local governments.

Yves Sintomer (sy@cmb.hu-berlin.de) Centre Marc Bloch, Schiffbauerdamm 19, D10117 Berlin, Germany, Carsten Herzberg (HCA@cmb.hu-berlin.de), Centre Marc Bloch, Schiffbauerdamm 19, D10117 Berlin, Germany, and Anja Röcke (anje.rocke@eui.eu), Department of Social and Political Studies, European University Institute, Badia Fiesolana, Via dei Rocettini 9, I-50014 San Domenico di Fiesole (FI), Italy.

\section{References}

Abers, R. (2000) Inventing local democracy. Grassroots politics in Brazil. Lynne Rienner Publishers, Boulder/London.

Allegretti, G. (2003) L'insegnamento di Porto Alegre. Autoprogettualità come paradigma urbano [The lesson of Porto Alegre. Self-managed project as urban pardigm]. Alinea, Florence.

Avritzer, L. (2002) Democracy and the public space in Latin America. 
Princeton University Press, Princeton, NJ.

Avritzer, L. (2005) Nouvelles spheres publiques au Brésil: démocratie locale et déliberation politique. In M. Bacqué, $\mathrm{H}$. Rey and Y. Sintomer (eds.), Gestion de proximité et démocratie participative, $\mathrm{La}$ Découverte, Paris.

Avritzer, L. (2006) New public spheres in Brazil: local democracy and deliberative politics. International Journal of Urban and Regional Research 30.3, 623-37.

Bacqué, M.-H., H. Rey and Y. Sintomer (eds.) (2005) Gestion de proximité et démocratie participative. La Découverte, Paris.

Baierle, S. (2006) Les ONG et l'insoutenable marchandisation de la solidarité.

Mouvements 47/48, September-December, 118-27.

Baiocchi, G. (2005) Militants and citizens: the politics of participatory democracy in Porto Alegre. Stanford University Press, Stanford, CA.

Bohman, J. and W. Rehg (1997) Deliberative democracy. MIT Press, Cambridge, MA.

Cabannes, Y. (ed.) (2003) Participatory budgeting and local finances. Network Urbal No. 9, Porto Alegre, PGU-ALC, European Community.

Cabannes, Y. (2004) Answers to 72 frequently asked questions about participatory budgeting, UMP-LAC, UN-HABITAT, UNDP, Quito.

Cabannes, Y. (2006) Les budgets participatifs en Amérique Latine. Mouvements 47, 128-38.

Chavez, D. and B. Goldfrank (2004) The Left in the city. Participatory local governments in Latin America. Latin America Bureau, London.

Cohen, J. (1989) Procedure and substance in deliberative democracy. In A. Hamlin and P. Pettit (eds.), The good polity: normative analysis of the state, Blackwell, Oxford.

Elster, J. (1998) Deliberative democracy. Cambridge University Press, Cambridge.

Fedozzi, L. (1999) Orçamento participativo. Reflexões sobre a experiência de Porto Alegre [Participative budgeting. Reflections on the experiement in Porto Alegre]. Tomo, Porto Alegre.

Fedozzi, L. (2000) O Poder da aldeia [Neighbourhood community power]. Tomo, Porto Alegre.

Fraser, N. (1996) Justice interruptus. Critical reflections on the 'postsocialist' condition. Routledge, New York/London.
Fung, A. and E. O. Wright (eds.) (2003) Deepening democracy: institutional innovations in empowered participatory governance. Verso, London/New York.

Gret, M. and Y. Sintomer (2005) The Porto Alegre experiment: learning lessons for a better democracy. Zed Books, London.

Habermas, J. (1996), Between facts and norms: contributions to a discourse theory of law and democracy. MIT Press, Cambridge, MA.

Herzberg, C. (2001) Der Bürgerhaushalt von Porto Alegre [The budget of Porto Alegre]. Lit-Verlag, Münster/Hamburg.

Marquetti, A. (2005) Characteristics of Brazilian cities experimenting with participatory budgeting. Working paper, PUCRS, Porto Alegre.

Marquetti, A., G. Campos and R. Pires (eds.) (2007) Democracia participativa e redistribuição: análise de experiências de orçamento participativo [Participative democracy and redistribution: analysis of experiments in participatory budgeting]. Ed. Xamã, São Paulo.

O’Donnell, G. (1994) Delegative democracy. Journal of Democracy 5.1, 55-69.

Röcke, A. (2005) Losverfahren und Demokratie. Historische und demokratietheoretische Perspektiven [Drawing lots and democracy: historical and democracy theory perspectives]. Lit-Verlag, Münster/Hamburg.

Santos, B. de Sousa (ed.) (2005) Democratizing democracy. Beyond the liberal democratic canon, London/New York: Verso.

Sintomer, Y., C. Herzberg and A. Röcke (eds.) (2005) Participatory budgets in a European comparative approach. Centre Marc Bloch / Hans-Böckler-Stiftung /Humboldt-Universität, Berlin. (Also available at www.buergerhaushalteuropa.de.)

Sintomer, Y., C. Herzberg and A. Röcke (forthcoming) Démocratie participative et modernisation des services publics: des affinités électives? Les budgets participatifs en Europe. La Découverte, Paris.

UNDP (2001) Human development report 2001. UNDP, New York. 


\section{Résumé}

Le 'transfert' du budget participatif du Brésil à l'Europe s'est révélé un processus très différencié. A Porto Alegre, cette méthodologie novatrice a permis d'intégrer démocratisation et justice sociale. En Europe, comme le budget participatif s'appuie sur de nombreuses procédures, il faut lui donner une définition méthodologique claire afin de pouvoir comparer correctement les cas et élaborer des idéaltypes pour comprendre la variété des expériences concrètes. Cet article propose six idéaltypes : Porto Alegre adapté à l'Europe, Représentation des intérêts organisés, Fonds communautaires au niveau local et municipal, Table de négociations public-privé, Consultation sur les finances publiques, Participation de proximité. Tous présentent des divergences frappantes, fortement influencées par les traditions participatives en place. C'est surtout avec les modèles Porto Alegre adapté à l'Europe et Fonds communautaires que peut se déployer une 'gouvernance participative dotée de pouvoirs' et que se développe un quatrième pouvoir, au-delà des trois autres classiques : celui de l'ensemble des citoyens exerçant directement (ou via des délégués) un pouvoir décisionnel. Toutefois, d'autres modèles ont leurs atouts également, par exemple vis-à-vis de la réforme de l'administration publique donc d'un aspect crucial dans la quête d'un 'autre monde possible'. 